\title{
Pengesanan Gelembung Plasma di dalam Lapisan Ionosfera menggunakan Penerima GPS di Asia Tenggara
}

(Detection of Plasma Bubble in Ionosphere using GPS Receivers in Southeast Asia)

\author{
SUHAila M BUHARI*, MARDina ABDUllah, YUichi OtSUKA, TATSUHIRO YOKOYAMA, \\ MiCHI NiSHIOKA, ALINA MARIE HASBI \& TAKUYA TSUGAWA
}

\begin{abstract}
ABSTRAK
Lapisan ionosfera berhampiran kawasan khatulistiwa geomagnetik sering terdedah kepada gangguan pada waktu malam yang dikenali sebagai gelembung plasma (РBB). Kehadiran PBB boleh meningkatkan kadar perubahan amplitud dan fasa isyarat radio yang melaluinya dan memberi kesan terhadap sistem komunikasi dan navigasi. PBB biasanya terjadi secara berturutan dengan satu demi satu struktur muncul pada waktu senja. Walau bagaimanapun, waktu dan lokasi kemunculan PBB tidak dapat diramal kerana punca awal pembentukannya masih belum dikenal pasti. Walaupun pelbagai peralatan telah dibangunkan untuk mencerap $P B B$, namun setiap alat pengukuran dibataskan oleh resolusi ruang dan masa. Dalam kajian ini, struktur PBB dalam dua dimensi (2D) dicerap menggunakan rangkaian penerima GPS dengan kepadatan yang tinggi di Asia Tenggara. Data GPS dikumpulkan daripada 127 stesen penerima dengan jarak sekitar 30 hingga $120 \mathrm{~km}$ di antara satu sama lain. Jumlah kandungan elektron (TEC) diperoleh berdasarkan perbezaan antara dua isyarat yang dipancarkan oleh setiap satelit GPS. Kehadiran PBB dikesan menggunakan indeks kadar perubahan TEC (ROTI) bagi semua laluan isyarat dari satelit kepada penerima. Struktur 2D PBB diperoleh dengan mempuratakan data GPS ROTI ke dalam grid bersaiz $0.45^{\circ}$ latitud $\times 0.45^{\circ}$ longitud dan dipetakan pada ketinggian $300 \mathrm{~km}$. Kajian kes pada malam 18 Mac 2011 menunjukkan kemunculan enam struktur PBB yang berturutan pada waktu senja apeks di sepanjang longitud $95^{\circ} \mathrm{T}$ hingga $120^{\circ} \mathrm{T}$. Struktur-struktur PBB tersebut muncul dengan jarak di antara 100 hingga 550 km. Jarak kemunculan sturuktur PBB memainkan peranan penting dalam menentukan punca pembentukannya yang dipercayai berbentuk seakan gelombang.
\end{abstract}

Kata kunci: Gelembung plasma; gangguan ionosfera; GPS TEC; GPS ROTI

\section{ABSTRACT}

The equatorial ionosphere most often shows a nighttime plasma irregularity that is commonly referred as equatorial plasma bubble $(P B B)$. The occurrence of $P B B$ could cause rapid fluctuations in the amplitude and phase of the propagation radio signals and crucial to communication and navigation systems. The PBB normally occur successively where one structure rising after another during the sunset time. However, the onset time and location of the PBB are ubiquitous because the seed of the initial perturbation is not completely understood. Although various observation systems have been developed to capture the EPB, each of the measurement is limited with space and time resolution. This study aims to observe 2D structure of the PBB using high-density GPS receivers in Southeast Asia. GPS data was collected from 127 GPS receivers in Southeast Asia with the spacing distances of 30-120 km from each other. Total electron content (TEC) was derived from the difference between two signals from each GPS satellite. The signature of the PBB was detected using rate of TEC change index (ROTI) for all the available satellites to receiver paths. The $2 D$ structure of the PBB was obtained by averaging GPS ROTI into $0.45^{\circ}$ latitude $\times 0.45^{\circ}$ longitude grid and projected at $300 \mathrm{~km}$ altitude. A case study on the night of 18 Mac 2011 showed the births of six PBB structures during the passage of the solar terminator along the $95^{\circ} \mathrm{E}$ to $120^{\circ} \mathrm{E}$ longitude. The separation distance between the PBB structures varied from 300 to $600 \mathrm{~km}$. The separation distance between the EPB structures play an important role in determining the source of the seeding mechanism that believed in a form of wavelike structure.

Keywords: Equatorial plasma buble; GPS TEC; GPS ROTI; ionospheric irregularities

\section{Pengenalan}

Lapisan ionosfera terbentuk melalui proses pengionan yang berlaku disebabkan oleh pancaran sinar ultraviolet (UV) ke atas atom dan molekul neutral di dalam lapisan atmosfera Bumi. Tenaga yang dipancarkan oleh sinar UV ke atas atom dan molekul tersebut menghasilkan ion dan elekton bebas yang dikenali sebagai plasma. Secara amnya, lapisan ionosfera berada pada altitud sekitar 50 km sehingga lebih $1000 \mathrm{~km}$ dari permukaan Bumi (Kelley 1989). Kajian ini memfokuskan fenomena gelembung plasma (PBB), iaitu gangguan yang berlaku di dalam lapisan ionosfera. Mekanisme pembentukan PBB boleh 
dijelaskan oleh teori ketidakstabilan Rayleigh-Taylor (RTI) yang diperkenalkan oleh Dungey pada tahun 1956 dengan cecair berketumpatan lebih rendah seperti minyak berada di bawah permukaan cecair yang lebih tumpat seperti air. Gangguan PBB berbentuk tiga dimensi (3D) dan menyerupai gelembung minyak yang mengatasi lapisan air yang berada di atas permukaannya. Sebarang daya yang dikenakan di antara dua lapisan tersebut akan mengakibatkan daya graviti menarik cecair yang lebih tumpat ke lapisan bawah, manakala cecair yang kurang tumpat akan bergerak ke permukaan atas cecair yang lebih tumpat. Ketumpatan plasma di dalam PBB yang rendah berbanding persekitarannya boleh menyebabkan isyarat radio yang melaluinya terserak. Sistem komunikasi radio dan navigasi boleh terjejas sekiranya isyarat yang dihantar atau diterima melintasi struktur PBB.

PBB biasanya muncul pada waktu senja kerana jumlah sinaran UV berkurangan daripada matahari. Keadaan tersebut menyebabkan proses pengionan di permukaan bawah lapisan ionosfera menjadi semakin perlahan, manakala proses penggabungan semula elektron dan zarah bercas berlaku lebih pantas. Fenomena PBB sering muncul berhampiran kawasan khatulistiwa geomagnetik kerana konfigurasi medan magnet yang selari dengan permukaan bumi. Struktur PBB pula berbentuk memanjang dari arah Utara ke Selatan hemisfera kerana konduktiviti plasma yang tinggi di sepanjang tiub fluks medan magnet Bumi (Otsuka et al. 2002). Asia Tenggara terletak berhampiran garisan khatulistiwa geomagnetik Bumi sering terdedah kepada gangguan PBB. Oleh itu, pelbagai peralatan telah dibangunkan bagi mengesan kehadiran strukrur PBB di rantau ini. Antara peralatan yang telah dibangunkan di Kototabang, Indonesia bagi mencerap PBB ialah sistem penderum radio (Saito \& Maruyama 2007), radar serakan balik (Ajith et al. 2015; Fukao et al. 2003; Yokoyama et al. 2004, 2011) dan pengimejan cahaya teja (Otsuka et al. 2004; Shiokawa et al. 2006, 2004). Walaupun pelbagai kajian telah dilakukan, penjelasan saintifik mengenai punca pembentukan PBB masih belum dapat dikenal pasti dengan tepat. PBB sering muncul dalam bulan-bulan ekuinoks, iaitu sekitar Mac dan September bagi rantau Asia Tenggara. Walau bagaimanapun, terdapat juga hari PBB muncul dalam bulan solstis dan tidak kelihatan dalam bulan ekuinoks. Struktur PBB didapati terbentuk secara berturutan dengan jarak sekitar 100 hingga $700 \mathrm{~km}$ di antara satu sama lain (Makela et al. 2010; Ram et al. 2014). Secara amnya, gangguan berbentuk seakan gelombang pada bawah permukaan lapisan ionosfera telah diterima sebagai punca pembentukan PBB yang paling munasabah. Gangguan seakan gelombang tersebut berpunca daripada perolakan gelombang graviti di dalam atmosfera (AGW) yang seterusnya membentuk struktur gelombang berskala besar (LSWS) di bawah lapisan ionosfera (Tsunoda 2015; Woodman 2009).

Data satelit telah dimanfaatkan untuk mengkaji topografi perubahan tanah dan hutan (Jaafar et al. 2009) serta pemetaan habitat terumbu karang (Mustapha et al. 2014). Selain itu, data daripada penerima GPS juga telah mula digunakan untuk mencerap cuaca angkasa (Wayan et al. 2009) serta penyelidikan bahaya tanah-tanah cerun (Yang \& Yeh 2016). Dalam kajian ini, data GPS daripada penerima di Asia Tenggara digunakan untuk mengesan kehadiran PBB. Data daripada penerima GPS dengan kepadatan yang tinggi di Asia Tenggara didapati berupaya mengesan PBB di kawasan yang lebih luas serta resolusi ruang dan masa yang lebih tinggi (Buhari et al. 2014). Rangkaian penerima GPS yang terlibat adalah Real-Time Kinematics GNSS Network Malaysia (MyRTKnet), GPS Sumatran Array (SuGAr) Array dan International GNSS Service (IGS) yang meliputi kawasan Malaysia, Indonesia dan Thailand. Struktur PBB yang terbentuk di sepanjang longitud cerapan dibentangkan dalam kajian ini.

\section{KAEDAH PENGESANAN PBB}

Data GPS dalam format Receiver Independent Exchange Format (RINEX) diperoleh dari setiap stesen penerima GPS yang terdapat di Asia Tenggara. Data GPS daripada rangkaian MyRTKnet yang terdiri daripada 78 buah stesen penerima boleh diperoleh secara terus dari Jabatan Pemetaan dan Ukur Malaysia (JUPEM). Data GPS dari rangkaian SuGAr dan IGS pula terdiri daripada 49 buah stesen penerima yang boleh dimuat turun dari pangkalan data Scripps Orbit and Permanent Array Center (SOPAC) melalui laman sesawang http://sopac.ucsd.edu/. Penerimapenerima GPS tersebut berada dalam lingkungan longitud $92^{\circ} \mathrm{T}$ sehingga $120^{\circ} \mathrm{T}$ dan latitud $12^{\circ} \mathrm{U}$ sehingga $8^{\circ} \mathrm{S}$. Rajah 1 menunjukkan taburan 127 penerima GPS yang terdapat di Asia Tenggara dengan jarak di antara 30 hingga $120 \mathrm{~km}$ antara satu sama lain.

Setiap satelit GPS mempunyai kod hingar rawak semu (PRN) yang unik dan memancarkan isyarat secara berterusan dalam dua frekuensi utama, iaitu $f_{1}=1575.42$ $\mathrm{MHz}$ dan $f_{2}=1227.60 \mathrm{MHz}$. Isyarat tersebut berbentuk gelombang elektromagnetik yang bergerak dengan halaju cahaya dan melalui lapisan ionosfera sebelum dicerap oleh penerima di permukaan Bumi. Julat semu $\left(L_{1}, L_{2}\right)$ boleh diperoleh dari fail RINEX bagi setiap $30 \mathrm{~s}$ dan memberikan pengukuran jarak yang dilalui oleh isyarat dari pemancar ke penerima dalam unit meter. Jumlah kandungan elektron di dalam lapisan ionosfera boleh ditentukan berdasarkan perbezaan antara dua isyarat tersebut $\left(L_{1}-L_{2}\right)$.

\section{JUMLAH KANDUNGAN ELEKTRON}

Jumlah kandungan plasma di dalam lapisan ionosfera boleh ditentukan berdasarkan jumlah kandungan elektron (TEC). TEC merupakan jumlah elektron dari satelit GPS kepada penerima yang terkandung di dalam satu unit luas permukaan keratan rentas $\left(\mathrm{m}^{2}\right)$. TEC diukur dalam unit TECU, 1 TECU bersamaan dengan $10^{16}$ elektron $\mathrm{m}^{-2}$. TEC boleh diperoleh berdasarkan perbezaan di antara dua isyarat yang dipancarkan oleh satelit GPS melalui persamaan berikut:

$$
T E C=\frac{1}{40.3}\left(\frac{f_{1}^{2} f_{2}^{2}}{f_{1}^{2}-f_{2}^{2}}\right)\left(L_{1}-L_{2}\right) T E C U,
$$




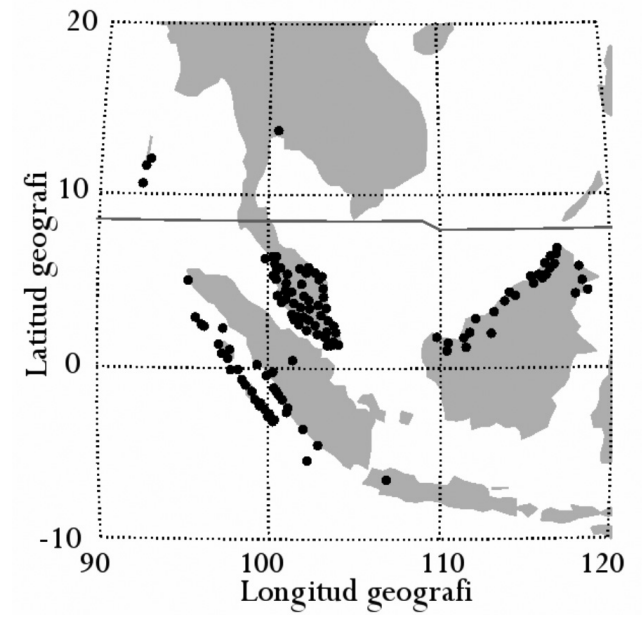

RAJAH 1. Taburan kedudukan penerima GPS dari rangkaian MyRTKnet, SuGAr, dan IGS di Asia Tenggara

dengan 40.3 merupakan pemalar yang diperoleh berdasarkan perlambatan isyarat yang terbias apabila melalui medium ionosfera. Seterusnya, $f_{1}$ dan $f_{2}$ masingmasing merupakan frekuensi isyarat yang dipancarkan oleh satelit GPS, manakala $L_{1}$ dan $\mathrm{L}_{2}$ merupakan julat semu bagi isyarat pada frekuensi $f_{1}$ dan $f_{2}$.

Rajah 2 menunjukkan contoh TEC yang diterbitkan bagi stesen penerima GPS di Simpang Renggam (SPGR) dengan longitud $1.81^{\circ} \mathrm{S}$ dan latitud $103.32^{\circ} \mathrm{T}$ pada $18 \mathrm{Mac}$ 2011. TEC dengan sudut dongakan yang kurang dari $35^{\circ}$ disingkirkan bagi meminimumkan ralat berbilang laluan yang terdapat pada sudut dongakan rendah. Paksi menegak menunjukkan nilai TEC dan paksi melintang menunjukkan masa universal (UT). TEC diplot dengan pelbagai warna yang mewakili PRN yang berasingan. Kehadiran PBB dapat diperhatikan dari penyusutan nilai TEC antara jam 1300 hingga 1700 waktu universal (UT), iaitu bersamaan dengan jam 2100 hingga 0100 waktu tempatan (LT). Kehadiran PBB dalam TEC diperhatikan mempunyai julat amplitud penyusutan yang besar, iaitu sehingga melebihi 10 TECU seperti yang ditandakan dengan petak berwarna merah.
Penyusutan nilai TEC yang kecil adalah hampir sama dengan perubahan nilai TEC yang diperoleh pada sudut dongakan yang berbeza. Oleh itu, kehadiran PBB sukar dikenal pasti berdasarkan amplitud penyusutan TEC yang terlalu kecil. Dalam kajian ini, kehadiran PBB dikenal pasti berdasarkan kadar perubahan TEC.

\section{KADAR PERUBAHAN TEC}

Ayunan nilai TEC yang disebabkan oleh kehadiran PBB boleh dikenal pasti berdasarkan kadar perubahan yang terdapat dalam nilai TEC. Kadar perubahan TEC (ROT) boleh mengesan ayunan kecil yang terdapat di dalam struktur PBB (Buhari et al. 2014; Nishioka et al. 2008). ROT dalam unit TECU $\mathrm{min}^{-1}$ boleh dikira melalui persamaan berikut;

$$
R O T=\frac{T E C(t+\Delta t)-T E C(t)}{\Delta t}
$$

dengan $t$ merupakan masa dan $\Delta t$ merupakan sela masa antara isyarat, iaitu $30 \mathrm{~s}$. Dalam kajian ini, sisihan piawai ROT bagi tempoh 5 min digunakan bagi mengesan kehadiran PBB. Sisihan piawai ROT dalam tempoh 5 min telah digunakan secara meluas dalam menentukan kehadiran gangguan di dalam ionosfera kerana mempunyai amplitud yang tinggi di dalam struktur PBB (Buhari et al. 2014; Nishioka 2008). Oleh itu, sisihan piawai ROT bagi tempoh 5 min digunakan dalam kajian ini yang turut dikenali sebagai indeks kadar perubahan TEC (ROTI).

Rajah 3 menunjukkan contoh ROTI yang diterbitkan berdasarkan TEC yang diplotkan dalam Rajah 2. Paksi menegak mewakili ROTI dalam unit TECU min $^{-1}$ dan paksi melintang merupakan masa dalam UT. Nilai ROTI didapati rendah pada waktu siang, iaitu sekitar jam 0000 hingga 1200 UT dan bersamaan dengan 0800 hingga 2000 LT. Kehadiran PBB dapat dikenal pasti berdasarkan nilai ROTI yang tinggi sehingga melebihi $1.0 \mathrm{TECU} \mathrm{min}^{-1}$ selepas waktu senja, iaitu antara 1300 hingga sekitar 1700 UT yang bersamaan dengan 2100 hingga 0100 LT. Nilai ROTI yang tinggi disebabkan oleh kadar perubahan TEC yang tinggi (Buhari et al. 2014). Oleh itu, ROTI merupakan penunjuk

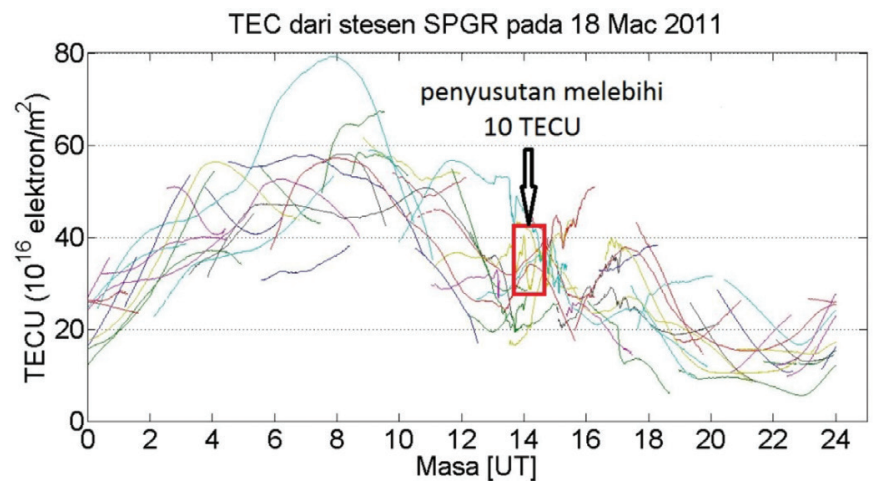

RAJAH 2. TEC yang diperoleh dari stesen penerima SPGR pada 18 Mac 2011. Kehadiran PBB dapat diperhatikan pada penyusutan nilai TEC di antara jam 1300 hingga 1700 UT. Penyusutan TEC sehingga melebihi 10 TECU direkodkan pada salah satu satelit 


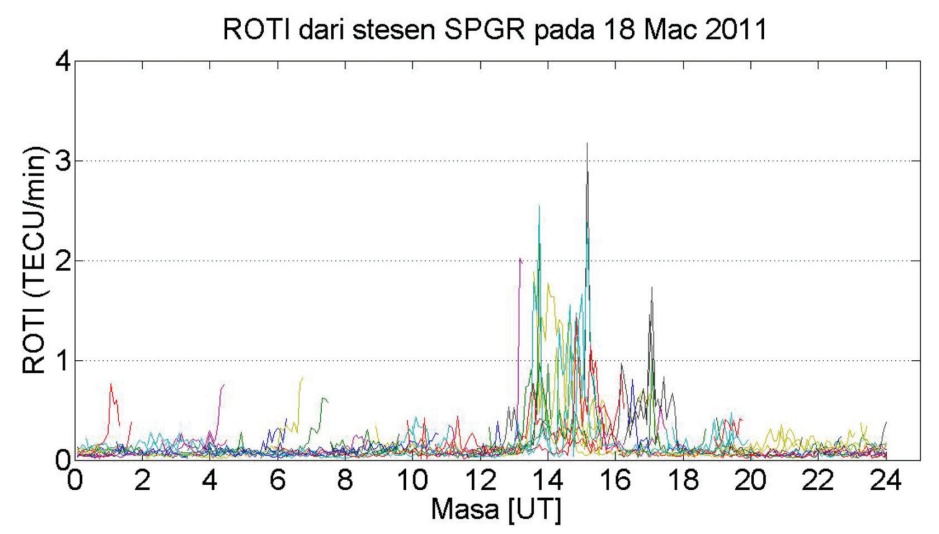

RAJAH 3. ROTI yang diperoleh dari stesen SPGR pada 18 Mac 2011. Kehadiran PBB dapat diperhatikan

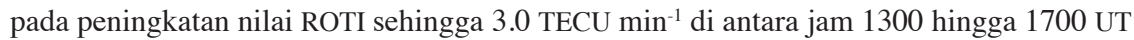

yang sesuai untuk mengesan gangguan yang terdapat di dalam lapisan ionosfera seperti PBB.

\section{PEMETAAN ROTI DALAM SATAH KOORDINAT GEOGRAFI}

Rajah 4 menunjukkan lapisan ionosfera yang dianggap sebagai model lapisan tunggal pada ketinggian 300 $\mathrm{km}$. ROTI boleh dipetakan pada pertemuan titik silang antara laluan isyarat dengan lapisan ionosfera (IPP) yang dianggarkan berada pada ketinggian $300 \mathrm{~km}$ (Saito \& Maruyama 2007). Latitud dan longitud pada IPP boleh diperoleh berdasarkan model Klobuchar. ROTI yang diperoleh bagi setiap laluan di antara satelit dan penerima dipuratakan ke dalam grid bersaiz $0.45^{\circ}$ latitud $\times 0.45^{\circ}$ longitud. Peta ROTI dalam satah koordinat geografi boleh diperoleh dalam sela masa 5 min dan berupaya mengesan gangguan yang terdapat di dalam struktur PBB dalam dua dimensi (2D).

Rajah 5 menunjukkan enam siri ROTI yang dipetakan dalam satah koordinat 2D pada malam 18 Mac 2011.

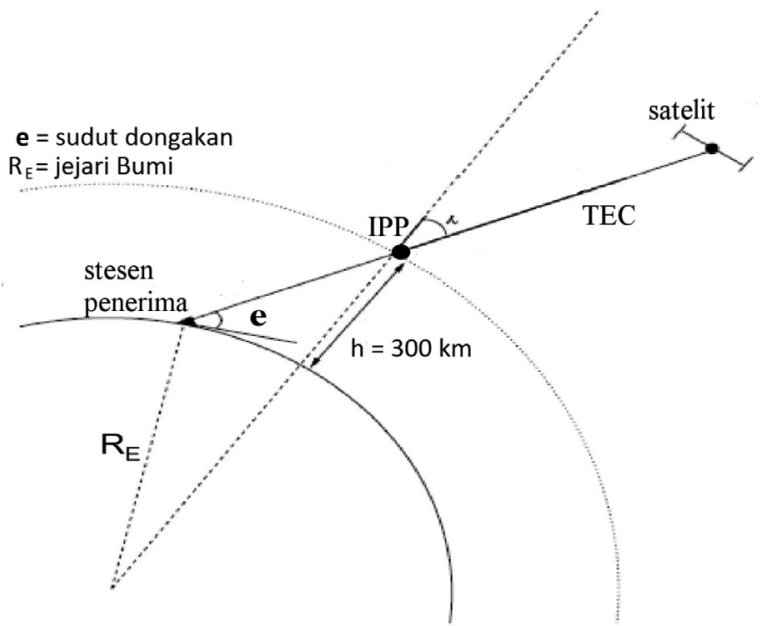

RAJAH 4. TEC diperoleh berdasarkan jarak yang dilalui oleh isyarat dari satelit kepada penerima. ROTI dipetakan pada IPP dengan mengandaikan ionosfera sebagai model lapisan tunggal pada ketinggian $300 \mathrm{~km}$
Paksi menegak merupakan latitud geografi, manakala paksi melintang merupakan longitud geografi. Skala warna menunjukkan nilai ROTI yang secara tidak langsung memperlihatkan darjah gangguan bersaiz puluhan kilometer yang terdapat di dalam struktur PBB. Masa bagi setiap rajah dicatatkan pada bahagian atas peta ROTI. Berdasarkan kajian lalu, struktur PBB didapati mempunyai bentuk yang memanjang dari arah Utara hingga ke Selatan garisan khatulistiwa geomagnetik. Selain itu struktur PBB didapati bergerak secara melintang dari arah Barat ke Timur kerana mengikuti arah pergerakan plasma di persekitarannya. Keamatan nilai ROTI berkadar terus dengan penyusutan nilai elektron di dalam lapisan ionosfera (Buhari et al. 2014). Pada jam 1250 UT, PBB kelihatan muncul sekitar longitud $116^{\circ} \mathrm{T}, 108^{\circ} \mathrm{T}$ dan $102^{\circ} \mathrm{T}$. PBB dengan intensiti sekitar 0.2 TECU min $^{-1}$ pada longitud $102^{\circ} \mathrm{T}$ ditandai dengan jalur kuning dan nombor 1 . Selang 10 min, intensiti PBB 1 didapati meningkat sehingga lebih 1.0 TECU min $^{-1}$ dan membesar ke semua arah seperti yang ditunjukkan dalam jalur kuning pada jam 1300 UT. Pada waktu yang sama, PBB baru juga didapati muncul di antara longitud $98^{\circ} \mathrm{T}$ hingga $100^{\circ} \mathrm{T}$ dan ditandakan dengan jalur merah dan nombor 2. Pada jam 1310 UT pula, struktur PBB 1 dan 2 kelihatan lebih besar berbanding pada jam 1300 UT, manakaala PBB yang baru kelihatan muncul pada bahagian Barat peta ROTI, iaitu sekitar $96^{\circ} \mathrm{T}$ dan ditandakan dengan jalur biru dan nombor 3. Pada jam 1320 UT, PBB 3 di dapati telah membesar ke semua arah dan PBB 1 dan 2 didapati bergerak ke arah Timur berbanding kedudukan awalnya, iaitu pada 1250 UT. PBB 1,2 dan 3 bergerak ke arah Timur pada jam 1330 dan 1340 UT. Selain itu, PBB 3 juga kelihatan jauh lebih besar berbanding sewaktu awal kemunculannya, iaitu pada 1310 UT.

\section{KERATAN RENTAS PETA GPS ROTI}

Rajah 5 menunjukkan struktur PBB dalam 2D yang dicerap pada masa yang berasingan. Gambaran keseluruhan aktiviti PBB dapat dilihat melalui keratan rentas peta ROTI yang dihimpunkan dalam satu malam seperti yang ditunjukkan dalam Rajah 6. Paksi menegak dalam Rajah 6 


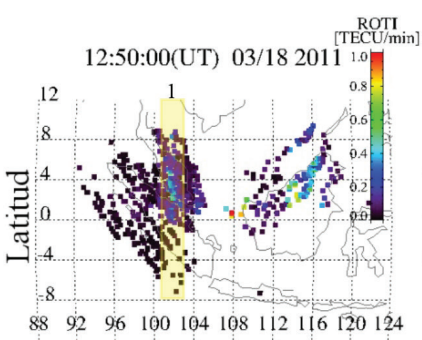

Longitud

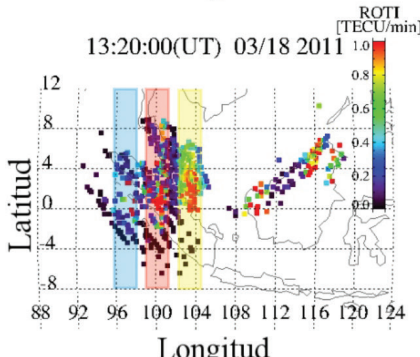

Longitud

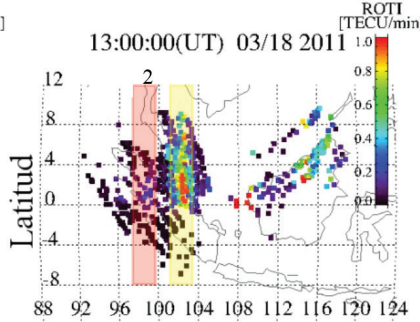

Longitud

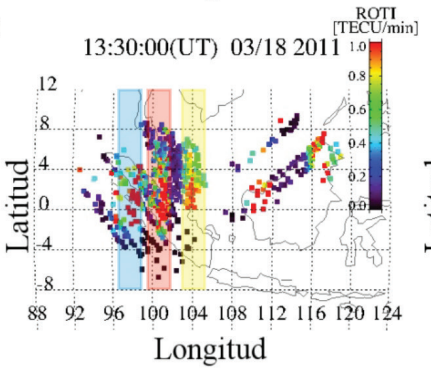

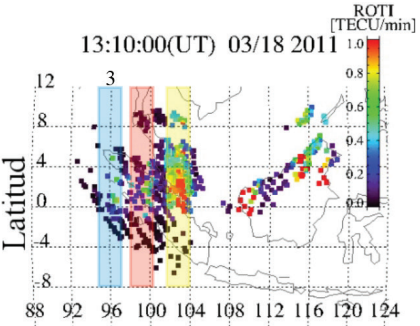

Longitud

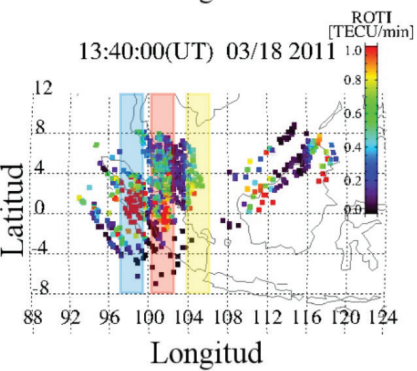

RAJAH 5. Struktur 2D PBB yang dikesan berdasarkan peta ROTI yang diplot pada IPP dan dipuratakan ke dalam grid bersaiz $0.45^{\circ}$ latitud $\times 0.45^{\circ}$ longitud koordinat geografi

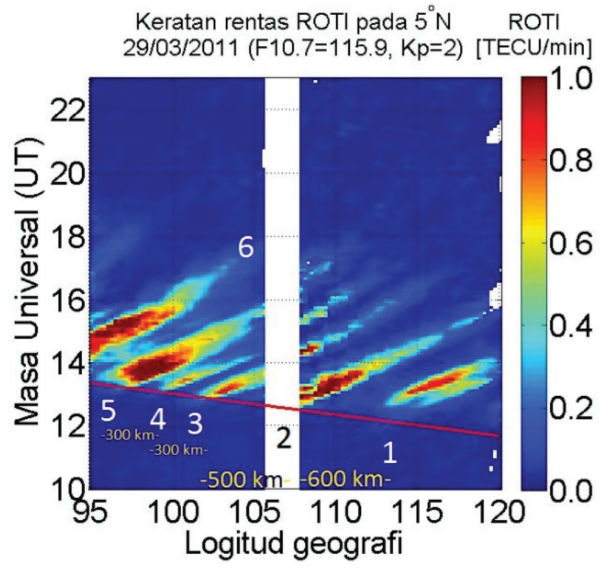

RAJAH 6. Keratan rentas ROTI dalam arah melintang (Timur dan Barat) yang diambil pada latitud $5^{\circ} \mathrm{U}$ menunjukkan enam struktur PBB muncul secara berturutan dengan jarak di antara 300 hingga $600 \mathrm{~km}$ pada waktu senja apeks. Waktu senja apeks ditandai dengan garisan merah

menunjukkan longitud geografi, manakala paksi melintang mewakili masa dari jam 1000 hingga 2300 UT. Keratan rentas tersebut diambil pada paksi melintang, $5^{\circ} \mathrm{U}$ dengan sela masa $5 \mathrm{~min}$. Garisan melintang pada longitud tersebut dipilih kerana mempunyai liputan GPS yang paling lebar. Kelompongan data dari sekitar longitud $105^{\circ} \mathrm{T}$ sehingga $110^{\circ} \mathrm{T}$ disebabkan oleh ketiadaan penerima GPS di kawasan laut. Garisan melintang berwarna merah menunjukkan waktu senja pada ketinggian $550 \mathrm{~km}$ di garisan khatulistiwa geomagnetik yang dikenali sebagai senja apeks. Keratan rentas ROTI yang ditunjukkan dalam Rajah 6 menunjukkan enam struktur PBB yang muncul di sepanjang longitud pada sewaktu senja apeks. Struktur PBB tersebut mula muncul secara berturutan di sepanjang garisan berwarna merah dari $95^{\circ} \mathrm{T}$ sehingga $120^{\circ} \mathrm{T}$. Keenam-enam struktur PBB tersebut diperhatikan bergerak ke arah Timur. Jarak di antara kemunculan struktur-struktur PBB tersebut didapati berbeza, iaitu dari 300 hingga $600 \mathrm{~km}$.

\section{PERBINCANGAN}

Kajian kes pada 18 Mac 2011 menunjukkan enam struktur PBB yang muncul dengan jarak di antara 300 hingga 600 $\mathrm{km}$ secara berturutan pada waktu senja apeks. Keputusan kajian ini selaras dengan kajian lalu yang menunjukkan PBB mempunyai jarak sekitar 100 hingga 700 km (Makela et al. 2010). Jarak tersebut juga berpadanan dengan jarak LSWS yang telah dikenal pasti sebagai punca pembentukan PBB (Ram et al. 2014). Pencerapan menggunakan GPS ROTI juga menunjukkan keenam-enam struktur PBB muncul secara berturutan sekitar waktu senja apeks. Hasil kajian ini bertepatan dengan hasil kajian Yokoyama et al. (2004) 
dengan gangguan bersaiz $3 \mathrm{~m}$ di dalam struktur PBB dicerap oleh radar serakan balik, Equatorial Atmosphere Radar (EAR) muncul pada waktu senja apeks. Fukao et al. (2006) telah menjangkakan jarak di antara kemunculan struktur-struktur PBB tersebut dengan mengektrapolasikan masa di antara struktur gumpalan yang dicerap oleh EAR. Sekiranya semua PBB muncul pada waktu senja apeks, EAR dengan medan pencerapan selebar $600 \mathrm{~km}$ dalam arah melintang (Timur dan Barat) tidak dapat mencerap lokasi kemunculan semua struktur PBB pada satu malam. Penerima GPS dengan liputan yang lebih luas didapati berupaya mencerap kemunculan beberapa struktur PBB dan menentukan jarak dan masa antara struktur tersebut. Kewujudan rangkaian penerima GPS di Asia Tenggara dapat melengkapi alat pencerapan yang terdapat di rantau ini seperti EAR.

Pencerapan melalui GPS ROTI dapat memantau evolusi PBB secara berterusan dan mengesan perubahan jarak antara PBB dengan lebih terperinci. Hari kemunculan PBB dipercayai dikawal oleh kewujudan struktur seakan gelombang pada bahagian bawah lapisan ionosfera yang seterusnya membentuk PBB melalui proses RTI (Buhari et al. 2014). Pembentukan struktur PBB yang berturutan pada waktu senja menunjukkan struktur seakan gelombang tersebut telah wujud di bawah permukaan lapisan ionosfera sebelum waktu senja apeks (Tsunoda 2015). Pada waktu senja, proses pengionan di bawah lapisan ionosfera menjadi semakin perlahan, manakala proses penggabungan semula semakin pantas menyebabkan lapisan ionosfera meningkat ke altitud yang lebih tinggi. Peningkatan tersebut menyebabkan permukaan bawah lapisan ionosfera menjadi tidak stabil dan menyebabkan proses RTI mudah berlaku yang seterusnya membentuk PBB.

Struktur seakan gelombang tersebut berpunca daripada perolakan AGW daripada lapisan troposfera (Shiokawa et al. 2006; Singh et al. 1997) yang seterusnya membentuk LSWS (Ram et al. 2014; Thampi et al. 2009; Tsunoda 2015). Kehadiran LSWS di bawah permukaan lapisan ionosfera telah dipertimbangkan sebagai punca pembentukan PBB. Makela et al. (2010) dan Makela dan Otsuka (2011) mendapati bahawa PBB dengan jarak di antara 100 hingga $400 \mathrm{~km}$ berpadanan dengan spektrum AGW yang dikesan oleh Vadas dan Crowley (2010). Hasil kajian ini mendapati struktur PBB mempunyai jarak di antara 300 hingga $600 \mathrm{~km}$ antara satu sama lain. Jarak di antara lokasi kemunculan PBB mempunyi kaitan dengan panjang gelombang LSWS yang wujud di bawah lapisan ionosfera sebelum waktu senja. Walau bagaimanapun, pencerapan LSWS adalah sukar dilakukan dan menyebabkan lokasi dan waktu kemunculan fenomena PBB tidak dapat diramal. Oleh itu, jarak antara struktur PBB yang dicerap dalam kajian ini dapat menyumbang ke arah kajian LSWS yang wujud sebelum waktu senja. Pengesanan kehadiran LSWS yang lebih awal dapat membantu proses mengenal pasti waktu dan lokasi kemunculan PBB dan membolehkannya pembentukannya diramal pada masa akan datang.

\section{KESIMPULAN}

Struktur PBB di sepanjang longitud di Asia Tenggara dan variasinya dengan masa telah diperoleh berdasarkan keratan rentas peta GPS ROTI secara melintang, iaitu pada arah Timur dan Barat. Oleh itu, lokasi dan masa pembentukan PBB di sepanjang longitud pencerapan dapat dikesan dengan tepat. Kajian kes pada malam 18 Mac menunjukkan enam struktur PBB muncul secara berterusan di antara $95^{\circ} \mathrm{T}$ hingga $120^{\circ} \mathrm{T}$ pada waktu senja apeks. Jarak di antara kemunculan struktur-struktur PBB tersebut adalah di antara 300 hingga $600 \mathrm{~km}$. Jarak di antara kemunculan struktur PBB adalah penting bagi mengenal pasti mekanisme pembentukan PBB. Hubungan antara jarak kemunculan PBB dengan LSWS hendaklah dikenal pasti pada masa akan datang.

\section{RUJUKAN}

Ajith, K.K., Ram, S.T., Yamamoto, M., Yokoyama, T., Gowtam, V.S., Otsuka, Y., Tsugawa, T. \& Niranjan, K. 2015. Explicit characteristics of evolutionary-type plasma bubbles observed from equatorial atmosphere radar during the low to moderate solar activity years 2010-2012. Journal of Geophysical Research 120: 1371-1382.

Buhari, S.M., Abdullah, M., Hasbi, A.M., Otsuka, Y., Yokoyama, T., Nishioka, M. \& Tsugawa, T. 2014. Continuous generation and two-dimensional structure of equatorial plasma bubbles observed by high-density GPS receivers in Southeast Asia. Journal of Geophysical Research 119(12): 10,569-10,580.

Fukao, S., Yokoyama, T., Tayama, T., Yamamoto, M., Maruyama, T. \& Saito, S. 2006. Eastward traverse of equatorial plasma plumes observed with the equatorial atmosphere radar in Indonesia. Annales Geophysicae 24: 1411-1418.

Jaafar, O., Sharifah Mastura, S.A. \& Sood, A.M. 2009. Land use and deforestation modelling of river catchments in Klang Valley, Malaysia. Sains Malaysiana 38(5): 655-664.

Kelley, M. 1989. The Earth's Ionosphere: Plasma Physics and Electrodynamics. San Diego, Carlifornia: Academic Press.

Makela, J.J. \& Otsuka, Y. 2011. Overview of nighttime ionospheric instabilities at low- and mid-latitudes: Coupling aspects resultin in structuring at the mesoscale. Space Science Review 168: 419-440.

Makela, J.J., Vadas, S.L., Muryanto, R., Duly, T. \& Crowley, G. 2010. Periodic spacing between consecutive equatorial plasma bubbles. Geophysical Research Letter 37: L14103. doi:10.1029/2010GL043968.

Mustapha, M.A., Lihan, T. \& Khalid, L.I. 2014. Coral reef and associated habitat mapping using ALOS satellite imagery. Sains Malaysiana 43(9): 1363-1371.

Nishioka, M., Saito, A. \& Tsugawa, T. 2008. Occurrence characteristics of plasma bubble derived from global ground based gps receiver networks. Journal of Geophysical Research 113: A05301. doi:10.1029/2007JA012605.

Otsuka, Y., Shiokawa, K., Ogawa, T. \& Wilkinson, P. 2002. Geomagnetic conjugate observations of equatorial airglow depletions. Geophysical Research Letter 29(15): 43-1 - 43-4). doi:10.1029/2002GL015347.

Ram, S.T., Yamamoto, M., Tsunoda, R.T., Chau, H.D., Hoang, T.L., Damtie, B., Wassaie, M., Yatini, C.Y., Manik, T. \& Tsugawa, T. 2014. Characteristics of large-scale wave structure observed from African and Southeast Asian 
longitudinal sectors. Journal of Geophysical Research 119: 2288-2297.

Saito, S. \& Maruyama, T. 2007. Large-scale longitudinal variation in ionospheric height and equatorial spread $F$ occurrences observed by ionosondes. Geophysical Research Letter 34: L16109. doi:10.1029/2007GL030618.

Singh, S., Johnson, F.S. \& Power, R.A. 1997. Gravity wave seeding of equatorial plasma bubbles. Journal of Geophysical Research 102(A4): 7399-7410.

Shiokawa, K., Otsuka, Y. \& Ogawa, T. 2006. Quasiperiodic southward moving waves in 630-nm airglow images in the equatorial thermosphere. Journal of Geophysical Research 111: A06301. doi:10.1029/2005JA011406.

Suparta, W., Yatim, B. \& Ali, M.A.M. 2009. Pemantauan dan pencirian cuaca angkasa di kawasan UKM Bangi, Selangor menggunakan penerima GPS. Sains Malaysiana 38(4): 463-471.

Thampi, S.V., Yamamoto, M., Tsunoda, R.T., Otsuka, Y., Tsugawa, T., Uemoto, J. \& Ishii, M. 2009. First observations of large-scale wave structure and equatorial spread $F$ using certo radio beacon on the c/nofs satellite. Geophysical Research Letter 36: L18111. doi:10.1029/2009GL039887.

Tsunoda, R.T. 2015. Upwelling: A unit of disturbance in equatorial spread $F$.Progress in Earth and Planetary Science 2: 9. doi: 10.1186/s40645-015-0038-5.

Vadas, S.L. \& Crowley, G. 2010. Sources of the traveling ionospheric disturbances observed by the ionospheric tiddbit sounder near Wallops Island on 30 October 2007. Journal of Geophysical Research 119: A07324. doi:10.1029/2009JA015053.

Woodman, R.F. 2009. Spread $F$ - an old equatorial aeronomy problem finally resolved? Annales Geophysicae 27: 19151934.

Yang, S.R. \& Yeh, Y.L. 2015. Geologic hazard risk assessment of slopeland villages in Southern Taiwan using remote sensing techniques. Sains Malaysiana 44(12): 1677-1683.

Yokoyama, T., Fukao, S. \& Yamamoto, M. 2004. Relationship of the onset of equatorial $F$ region irregularities with the sunset terminator observed with the equatorial atmosphere radar. Geophysical Research Letter 3: L24804. doi:10.1029/2004GL021529.
Suhaila M Buhari*

Jabatan Fizik, Fakulti Sains

Universiti Teknologi Malaysia

81310 UTM, Johor Bahru, Johor Darul Takzim

Malaysia

Mardina Abdullah

Pusat Sains Angkasa, Institut Perubahan Iklim

Universiti Kebangsaan Malaysia

43600 UKM Bangi, Selangor Darul Ehsan

Malaysia

Yuichi Otsuka

Institute for Space-Earth Environmental Research

Nagoya University

Japan

Tatsuhiro Yokoyama, Michi Nishioka \& Takuya Tsugawa National Institute of Information and Communications Technology

Japan

Alina Marie Hasbi

Department of Electrical, Electronic and Systems Engineering Faculty of Engineering and Built Environment

Universiti Kebangsaan Malaysia 43600 UKM Bangi, Selangor Darul Ehsan Malaysia

*Pengarang untuk surat-menyurat; email: suhailamb@utm.my

Diserahkan: 30 Jun 2016

Diterima: 10 November 2016 